\title{
KARIÉRNE KOMPETENCIE AKO PREDIKTORY KARIÉRNEHO ÚSPECHU
}

\author{
IVANA MAGÁČOVÁ ŽILKOVÁ
}

\begin{abstract}
Prezentovaný príspevok sa zaoberá konceptom kariérnych kompetencií. Ciel'om štúdie bolo zistit', či existuje vzt’ah medzi kariérnymi kompetenciami a kariérnym úspechom. Kariérne kompetencie boli merané prostredníctvom dotazníka CCI (Career Competencies Indicators). Subjektívny a objektívny kariérny úspech bol vo výskume sledovaný prostredníctvom štyroch ukazovatel'ov, a to kariérna spokojnost', vnímaná zamestnatel'nost', plat a počet povýšení. Výskumný súbor pozostával z 206 zamestnaných osôb s priemerným vekom 29,45 rokov. K štatistickej analýze údajov bol použitý výpočet korelačných koeficientov a viacnásobnej hierarchickej lineárnej regresie. Výsledky preukázali významný pozitívny vztah medzi kariérnymi kompetenciami a ukazovatel'mi kariérna spokojnost', vnímaná zamestnatel'nost' a počet povýšení. Výsledky výskumu tak podporili dôležitost' kariérnych kompetencií pre úspešný kariérny vývin.
\end{abstract}

Kl'účové slová: kariérne kompetencie, kariérny úspech, kariérové poradenstvo, Slovenská republika https://doi.org/10.14712/23366486.2019.3

\section{Úvod}

Globálne ekonomické a sociálne zmeny, ktoré nastali v posledných desat'ročiach mali zásadný dopad na trh práce a kariéru jednotlivca. V súčasnosti sa v kariére zdôrazňuje tzv. self-management, čiže vlastné riadenie osobnej kariéry, za čo preberá zodpovednost' jedinec samotný a v tejto súvislosti sa v psychológii a moderných koncepciách kariéry objavuje koncept kariérnych kompetencií. Kariérne kompetencie považuje Lo Presti (2009) za prístup k posilneniu riadenia vlastnej kariéry. V súvislosti s uvedeným trendom a vzrastajúcim významom kariérnych kompetencií nás preto zaujíma, do akej miery kariérne kompetencie determinujú riadenie kariéry jednotlivca a tým prispievajú k predikcii kariérneho úspechu. $\mathrm{V}$ našom výskume sme zist'ovali vzt'ah medzi kariérnymi kompetenciami a kariérnym úspechom pri kontrole vplyvu sociodemografických faktorov (vek, pohlavie, vzdelanie).

\section{Teoretické východiská}

V súčasnosti zaznamenávame niekol'ko prístupov k definovaniu kompetencií. Tieto prístupy napr. Kubeš et al. (2004) člení do troch kategórií: 
1. kompetencie ako pomenovanie spôsobov l'udského správania. Ide o operacionálne definície vymedzujúce kompetencie v pojmoch správania, čiže kompetencie sú chápané ako pozorovatel'né správanie;

2. rysové ponímanie kompetencií, kedy sú kompetencie využívané ako nástroj deskripcie jednotlivca po osobnostnej stránke. To znamená, že kompetencie sú chápané ako osobnostné charakteristiky, teda predpoklady správania;

3. kompetencie definované v zmysle premietnutia jedincových možností do výkonov.

Z uvedeného vyplýva, že autori k definovaniu kompetencií využívajú bud’ rysový prístup alebo behaviorálny prístup, avšak stále platí, že tieto definície majú jeden spoločný menovatel', a to väzbu na efektívny výkon. Z toho vyplýva, že kompetencie s atribútom kariérne, napomáhajú $\mathrm{k}$ efektívnym výsledkom v kariére a teda ul'ahčujú kariérny vývin v rýchlo sa rozvíjajúcom kariérnom prostredí (Lichtenstein \& Mendenhall, 2002). Možno ich preto považovat' za zásadný klúč ku kariérnemu úspechu, sú potrebné k posunu smerom k uspokojivému zamestnaniu, uvedomeniu si svojich schopností, nadania (Beheshtifar \& Zare, 2013), k identifikácii svojich vlastných pohnútok a motivácie, k vedomému získavaniu prenosných schopností, aktívnemu budovaniu sietí kontaktov a pod. (Eby et al., 2003). Kariérne kompetencie poskytujú jasnú cestu k individuálnym výkonom v priebehu svojej kariéry (Beheshtifar \& Zare, 2013) a sú hodnotené v rámci jednotlivcom zvolenej kariére (Eby et al., 2003). Kariérne kompetencie sa vyznačujú premenlivostou správania, z čoho vyplýva, že je možné ich „trénovat“", učit' sa im a rozvíjat' ich (Francis-Smythe et al., 2013). Dalej pre ne platí, že idú nad rámec technických a manažérskych zručností (Lichtenstein \& Mendenhall, 2002), sú preto relevantné pre všetkých zamestnancov k rozvoju svojej vlastnej kariéry, bez ohladu na špecifikáciu práce, ktorú vykonávajú (Kuijpers \& Scheerens, 2006).

\section{KARIÉRNE KOMPETENCIE AKO PREDIKTORY KARIÉRNEHO ÚSPECHU}

Už od 60. rokov patria medzi najfrekventovanejšie v sociológii a ekonómii výskumy zaoberajúce sa tým, čo určuje životný úspech jednotlivca vrátane úspechu na trhu práce (Matějů \& Anýžová, 2015). Inak tomu nie je ani v psychológii, kde výsledky mnohých výskumov podporili dôležitost' kariérnych kompetencií ako prediktorov úspechu v kariére. Eby et al. (2003) vo svojej štúdii potvrdili vzt’ahy medzi kariérnymi kompetenciami a troma ukazovatel'mi kariérneho úspechu, a to vnímanou kariérnou spokojnost'ou, a vnímanou internou a externou zamestnatelnost'ou. Bol potvrdený pozitívny vzt'ah medzi kompetenciami knowing-why (proaktívna osobnost', otvorenost' voči skúsenosti, kariérny vhl'ad) a všetkými ukazovatel'mi kariérneho úspechu. Z pomedzi kompetencií knowing-whom boli interné a externé siete kontaktov v pozitívnom vztahu s kariérnou spokojnostou a internou zamestnatel'nost'ou. Skúsenost' s mentorovaním sa tu neukázala ako signifikantný prediktor. Vnímaná externá zamestnatel'nost' bola vo vzt’ahu so všetkými troma kompetenciami knowing-whom. Kompetencie knowing-how (kariérne zručnosti) pozitívne korelovali so všetkými troma ukazovatel'mi kariérneho úspechu. Autori zároveň zistovali mieru predikcie kariérnych kompetencií na ukazovatele kariérneho úspechu. Kariérnu spokojnost' v najväčšej miere predikovali kompetencie knowing-why (43,6 \%). Vnímanú internú zamestnatel'nost' rovnako kompetencie knowing-why (41,7 \%). Vnímanú externú zamestnatel'nost' v najväčšej miere predikovali kompetencie knowing-how (46,1 \%) (Eby et al., 2003). 
Aj d’alšie štúdie dokazujú, že kompetencie knowing-why, knowing-whom a knowinghow sú užitočné pre predikciu objektívneho a subjektívneho kariérneho úspechu (Singh, Ragins \& Tharenou, 2009). Day a Allen (2004) skúmali kariérnu odolnost' ako kompetenciu knowing-why a zistili, že pozitívne súvisí s objektívnym a subjektívnym kariérnym úspechom. Eddleston et al. (2004) zistili, že kariérna netrpezlivost' (ako knowing-why kompetencia) pozitívne koreluje s kariérnym úspechom. Dreher a Bretz (1991) zistili, že nadobúdanie zručností a vedomostí (ako kompetencia knowing-how) pozitívne koreluje s kariérnym úspechom. Ng et al. (2005) tiež poukázali na to, že pracovné zručnosti a pracovné skúsenosti (ako kompetencie knowing-how) sú spojené s kariérnym úspechom. Interné a externé siete kontaktov (ako kompetencie knowing-whom) pozitívne korelovali s ukazovatel'mi objektívneho kariérneho úspechu, konkrétne s počtom povýšení a pracovnými mobilitami (Ng et al., 2005). Rovnako Forret a Dougherty (2004) zistili, že vytváranie sietí kontaktov pomáha $\mathrm{k}$ dosiahnutiu objektívneho a subjektívneho kariérneho úspechu. Niektorí autori považujú kompetenciu siete kontaktov za základný prvok úspechu v kariére, nakol'ko so zníženou istotou zamestnania je pre jednotlivcov potrebné byt' kontaktmi dobre prepojený v rámci aj mimo svojej organizácie, čo zabezpečuje podporu a pomoc v kariérnom vývine (Arthur \& Rousseau, 1996; DeFillippi \& Arthur, 1994; Higgins \& Kram, 2001). Vzt'ah medzi kariérnymi kompetenciami a kariérnym úspechom potvrdili vo svojej štúdii tiež Francis-Smythe et al. (2013), ktorí však zistili, že kariérne kompetencie vo významnejšej miere predikujú subjektívny ako objektívny úspech. Aj Kuijpers, Schyns et al. (2006) ponúkajú prehl’ad o tom, ako kariérne kompetencie súvisia so subjektívnym a objektívnym kariérnym úspechom. Čo sa týka subjektívneho kariérneho úspechu, bol v pozitívnom vzt’ahu s kompetenciami schopnost' kariérnej aktualizácie, kariérne riadenie a vytváranie sietí kontaktov a naopak v negatívnom vzt’ahu s kompetenciou reflexia motivácie. K objektívnemu kariérnemu úspechu pozitívne prispeli kompetencie schopnost' kariérnej aktualizácie a vytváranie sietí kontaktov, naopak kompetencia reflexia motivácie sa ukázala opät' v negatívnom vzt’ahu. Vysvetl'ujú to tým, že zamestnanci, ktorí skúmajú, či ich práca zodpovedá ich osobným hodnotám, zažívajú menej kariérneho úspechu než tí, ktorí týmto spôsobom neskúmajú svoju prácu. Vysvetlenie môže spočívat' aj v tom, že jedinec, ktorý zažíva malý kariérny úspech, je nabádaný k zamysleniu sa nad jeho vlastnými motívmi. Chang et al. (2014) vo svojej štúdii uplatnili širší pohl'ad pri skúmaní kariérnych kompetencií, nakol'ko predchádzajúci výskumníci analyzovali kariérny úspech len na organizačnej úrovni alebo na úrovni jednotlivca. Vo svojej štúdii sa pokúsili preklenút priepast' medzi oboma prístupmi a snažili sa zistit', či kariérne poradenstvo v organizácii a individuálne riadenie kariéry majú moderujúci efekt na vzt’ah medzi kariérnymi kompetenciami a kariérnym úspechom. Kariérne kompetencie pozitívne korelovali s ukazovatel'mi subjektívneho (kariérny rast, zamestnatel'nost') a objektívneho (plat) kariérneho úspechu. Zároveň zistili, že kariérne poradenstvo a individuálny kariérny manažment mali signifikantný pozitívny efekt na subjektívny kariérny úspech, ale nie na objektívny.

V tomto kontexte nesmieme opomenút' ani význam sociodemografických faktorov, ktoré vstupujú do vzt’ahu medzi kompetenciami a úspechom. V štúdiách zaoberajúcich sa l’udským kapitálom sa dížka vzdelania dlhú dobu považovala za základ produktivity pracovníka, avšak na problémy súvisiace s týmto presvedčením sa poukazuje už niekol'ko rokov (Mincer, 1970; DeLong \& Summers, 1992, in Matějů \& Anýžová, 2015) a kritizovalo sa najmä to, že počet rokov vzdelania bol považovaný za meradlo l'udského kapitálu 
so zanedbaním kvalitatívnych rozdielov vo výsledných znalostiach. Dnes možno na základe mnohých štúdií a analýz konštatovat', že dosiahnuté vzdelanie možno považovat' len za jednu z príčin nameraných kompetencií, avšak platí, že možnost' dostat' sa na určitý stupeň vzdelania je spravidla podmienená preukázatel'nými schopnost’ami a znalost’ami. A teda platí, že kompetencie sú jednak produktom vzdelávania ako aj socializácie. V kontexte sociodemografických faktorov je rovnako dôležité zaoberat' sa rodovými rozdielmi pri zist'ovaní vplyvu kompetencií na dosahovanie úspechu, napr. príjmu. Výsledky mnohých výskumov a analýz potvrdzujú, že muži a ženy sú si v meraných kompetenciách omnoho podobnejší ako v školskom prospechu, avšak napriek tomu boli potvrdené vel'ké rozdiely medzi mužmi a ženami vo výške platu. Na Slovensku majú ženy v priemere o 32 \% nižší plat ako muži (Matějů \& Anýžová, 2015).

Na základe doterajších výskumných zistení možno konštatovat', že kariérne kompetencie sa významným spôsobom podiel’ajú na dosahovaní kariérneho úspechu, ktorý je zároveň determinovaný aj inými sociodemografickými faktormi, preto sme sa rozhodli tieto skutočnosti overit’ aj vo vlastnej štúdii.

\section{Ciel' výskumu, výskumné otázky a hypotézy}

Ciel'om našej štúdie bolo zistit' vzt'ahy medzi kariérnymi kompetenciami a kariérnym úspechom, konkrétne medzi siedmymi kariérnymi kompetenciami 1. sebaprezentácia a hl’adanie spätnej väzby; 2. efektivita súvisiaca s výkonom práce; 3.stanovenie ciel’ov a plánovanie kariéry; 4 . sebapoznanie; 5 . vytváranie siete kontaktov a vzt’ahov s mentormi; 6. znalost' firemnej politiky a štruktúr príležitostí; 7. zručnosti súvisiace s kariérou a ukazovatel'mi subjektívneho (kariérna spokojnost', vnímaná zamestnatel'nost') a objektívneho (plat, počet povýšení) kariérneho úspechu, pri kontrole vplyvu sociodemografických faktorov (vek, pohlavie, vzdelanie).

V našej štúdii sme hl'adali odpovede na otázky, či a do akej miery sa kariérne kompetencie podielajú na dosahovaní subjektívneho a objektívneho kariérneho úspechu, teda či sú kariérne kompetencie štatisticky významnými determinantami resp. prediktormi objektívneho a subjektívneho kariérneho úspechu.

Na základe doterajších výskumných zistení sme predpokladali, že kariérne kompetencie budú v štatisticky významnom pozitívnom vztahu s kariérnou spokojnostou, vnímanou zamestnatel'nost'ou, platom a počtom povýšení.

\section{Metóda}

\section{VÝSKUMNÝ SÚBOR}

Výskumný súbor bol vybraný nenáhodným, príležitostným spôsobom. Respondentom bola prostredníctvom sociálnych sietí alebo emailu poslaná pozvánka na účast' vo výskume s odkazom na webovú adresu online dotazníka. Vyplnený dotazník vrátilo 206 respondentov, čo predstavovalo 30\% návratnost'. Jedinou podmienkou, ktorú museli respondenti splnit', aby boli zaradení do výskumu, bola zamestnanost' jedinca. 100 respondentov pracovalo $\mathrm{v}$ štátnom sektore (oblast’ školstva, poradenstva, zdravotníctva) 
a 106 respondentov v súkromnom sektore (oblast' bankovníctva, predaja, služieb). Čo sa týka pracovnej pozície v rámci hierarchie organizácie, 17,5\% respondentov zastávalo manažérske pozície; 42,6 \% respondentov predstavovalo vysokokvalifikovaných odborníkov, 39,9 \% radových zamestnancov. Väčšina respondentov pracovala v Prešovskom a Košickom kraji (82 \%). Vek našich respondentov sa pohyboval v rozmedzí od 19 do 50 rokov $(M=29,45$; $S D=7,85)$, z toho bolo 74 mužov a 132 žien. Vzdelanie respondentov bolo stredoškolské $(30,1 \%)$, vysokoškolské 1 . stupňa $(13,1 \%)$, vysokoškolské 2. stupňa (52,9\%) a vysokoškolské 3.stupňa $(3,9 \%)$.

\section{Výskumné nástroje}

\section{CAREER COMPETENCIES INDICATORS - INDIKÁTORY KARIÉRNYCH KOMPETENCIÍ}

Dotazník Career Competencies Indicators (CCI) (Francis-Smythe et al., 2013) slúži k posúdeniu kariérnych kompetencií jedinca. Dotazník obsahuje 43 položiek, prostredníctvom ktorých zist'uje mieru siedmych kariérnych kompetencií, a to sebaprezentácia a hl'adanie spätnej väzby; efektivita súvisiaca s výkonom práce; stanovenie ciel’ov a plánovanie kariéry; sebapoznanie; vytváranie siete kontaktov a vzt'ahov s mentormi; znalost' firemnej politiky a štruktúr príležitostí; zručnosti súvisiace s kariérou. Tieto kompetencie zároven̆ predstavujú sedem škál dotazníka. Respondent odpovedá na 5bodovej Likertovej stupnici (1 - silne nesúhlasím; 5 - silne súhlasím). Dotazník bol preložený z anglického do slovenského jazyka. Preklad prebiehal v spolupráci s odbornými prekladatel'mi a konzultáciami s autormi. O preklad boli požiadaní dvaja odborní prekladatelia a taktiež študent psychológie s vel'mi dobrým jazykovým vybavením, čo sa týka anglického jazyka. Následne bol z týchto čiastočne sa líšiacich prekladov vytvorený zjednotený preklad, ktorý prešiel proof-readingom lektora jazykovej školy. Jednotlivé kroky boli konzultované s autormi. Následne bol dotazník overovaný vo validačnej štúdii, ktorá priniesla niekol'ko dôkazov validity a reliability. Reliabilita pôvodnej verzie jednotlivých škál sa pohybuje v rozmedzí $\alpha=, 69$ až ,87.

\section{HODNOTENIE KARIÉRNEHO ÚSPECHU}

Kariérny úspech sme hodnotili prostredníctvom štyroch ukazovatel'ov. Ako ukazovatele subjektívneho kariérneho úspechu boli zvolené kariérna spokojnost' a vnímaná zamestnatel'nost'. Ako ukazovatele objektívneho kariérneho úspechu boli zvolené plat a počet povýšení. Výška platu bola zist'ovaná ako priemerný mesačný čistý plat. Pri analýze počtu povýšení sme vychádzali z ponímania Francis-Smythe et al. (2013), ktorí povýšenie definujú ako pracovný pohyb (mobilitu), ktorý zahŕňa nasledujúce možností: významné zvýšenie rozsahu zodpovednosti, zvýšenie ročného platu, zmeny v úrovni (organizačnej štruktúre) v zamestnávajúcej spoločnosti, vyšší nárok na bonusy alebo viac bonusov. Toto širšie poňatie povýšenia bolo aplikované s ciel'om zaistit', aby bolo povýšenie považované nielen za vertikálne pohyby po rebríku (v hierarchii organizácie), ale aj ako pohyby do bočných, viac špecializovaných rolí. Respondenti v našom výskume mali ku každému z vyššie uvedených možností povýšenia uviest' počet ich dosiahnutia od nástupu do zamestnania. 
K hodnoteniu subjektívneho kariérneho úspechu sme použili dva nasledujúce nástroje, ktoré boli preložené z anglického do slovenského jazyka dvoma nezávislými odbornými prekladatel'mi a zjednotené, pričom výsledný preklad taktiež prešiel proof-readingom lektora jazykovej školy.

\section{CAREER SATISFACTION SCALE - ŠKÁLA KARIÉRNEJ SPOKOJNOSTI}

Autormi dotazníka sú Greenhause, Parasuraman a Wormley (1990). Dotazník meria spokojnost's kariérou, ktorá je považovaná za základný ukazovatel' subjektívneho kariérneho úspechu. Okrem celkovej spokojnosti s rozvojom kariéry sa pomocou tejto škály hodnotí aj spokojnost' s úrovňou zárobku, povýšenia a rozvojom schopností (Fields, 2002). Dotazník pozostáva z 5 položiek (,,Som spokojný/á s úspechom, ktorý som dosiahol/a v mojej kariére. "). Koeficient reliability sa pohybuje v rozsahu $\alpha=, 83$ až ,89 (Fields, 2002). Cronbachova alfa škály v našom výskume bola $\alpha=, 88$.

\section{SELF-RATED (PERCEIVED) EMPLOYABILITY SCALE - ŠKÁLA VNÍMANEJ ZAMESTNATELNOSTI}

Škála vnímanej zamestnatel'nosti je nástroj na hodnotenie vnímanej zamestnatel'nosti vyvinutý autormi De Cuyper a De Witte (2008). Škála zist'uje mieru, v akej jedinec vníma svoju vlastnú cenu, hodnotu na trhu práce. Hodnotí teda vnímanú spôsobilost' jedinca začlenit' sa do pracovného života, schopnost' získat' alebo udržat' si zamestnanie. Škála pozostáva z 8 položiek (,,Lahko nájdem inú prácu, ked’ stratím túto prácu. “). Reliabilita nástroja je $\alpha=, 84$, v našom výskume bola $\alpha=, 81$.

\section{Výsledky}

V prvom kroku sme vykonali výpočet korelácií (pearsonov korelačný koeficient) medzi kariérnymi kompetenciami a ukazovatel'mi kariérneho úspechu a v druhom kroku sme vykonali viacnásobnú hierarchickú lineárnu regresiu, pomocou metódy stepwise. V Tab. 1 uvádzame hodnoty korelačných koeficientov a v Tab. 2 výsledky regresnej analýzy.

Tabulka1 Korelácie medzi kariérnymi kompetenciami a ukazovatel’mi kariérneho úspechu

\begin{tabular}{|l|c|c|c|c|}
\hline & Kariérna spokojnost' & Vnimaná zamestnatel'nost' & Plat & Počet povýšení \\
\hline CCI_S &, $353^{* * *}$ &, $220^{* *}$ &, 117 &, $284^{* * *}$ \\
\hline CCI_E &, $167^{*}$ &, 046 &, 017 &, 126 \\
\hline CCI_G &, $443^{* * *}$ &, $310^{* * *}$ &, 052 &, $287^{* * *}$ \\
\hline CCI_K &, $334^{* * *}$ &, $197^{* *}$ &, 124 &, $244^{*}$ \\
\hline CCI_N &, $324^{* * *}$ &, $290^{* * *}$ &, 101 &, $262^{* * *}$ \\
\hline CCI_O &, $358^{* * *}$ &, $330^{* * *}$ &, 115 &, $313^{* * *}$ \\
\hline CCI_C &, $379^{* * *}$ &, $245^{* * *}$ &, $165^{*}$ &, $295^{* * *}$ \\
\hline
\end{tabular}

Poznámka: *** $\mathrm{p}<, 001, * * \mathrm{p}<, 01, * \mathrm{p} \leq, 05$; CCI_S - Sebaprezentácia a hl’adanie spätnej väzby; CCI_E - Efektivita súvisiaca s výkonom práce; CC̄I_G - Stanovenie ciel'ov a plánovanie kariéry; CCI_K - Sebapoznanie; CCI_N - Vytváranie siete kontaktov a vzt'ahov s mentormi; CCI_O - Znalost' firemnej politiky a štruktúr príležitostí; CCI_C - Zručnosti súvisiace s kariérou. 
Z tabul'ky vyplýva, že kariérne kompetencie sú v štatisticky významnom pozitívnom vzt’ahu s kariérnou spokojnost'ou, vnímanou zamestnatel'nost’ou a počtom povýšení. To znamená, že miera kariérneho úspechu u týchto ukazovatel'ov je tým vyššia, čím viac osoba disponuje kariérnymi kompetenciami. Na rozdiel od toho, vzt’ah medzi kariérnymi kompetenciami a štvrtým ukazovatel'om (platom) sa nepreukázal, s výnimkou jednej kompetencie, a to zručnosti súvisiace s kariérou. V nasledujúcej tabul'ke uvádzame výsledky regresnej analýzy pre kariérne kompetencie a sociodemografické faktory ako prediktory a ukazovatele subjektívneho a objektívneho kariérneho úspechu ako kritériá.

Tabulka 2 Regresné modely pre škály CCI a sociodemografické faktory (vek, pohlavie, vzdelanie) ako prediktory a ukazovatele SKÚ a OKÚ (kariérna spokojnost', vnimaná zamestnatel'nost', plat, počet povišsení) ako kritériá (akceptované modely; $p<, 05$ )

\begin{tabular}{|c|c|c|c|c|c|}
\hline Prediktor & $\mathbf{R}$ & R2-change & B & $\mathbf{T}$ & $\mathbf{p}$ \\
\hline \multicolumn{6}{|c|}{ SKÚ - Kariérna spokojnost' $\left(\mathbf{F}_{\text {total }}(2,203)=29,107 ; \mathbf{p} \leq \mathbf{. 0 0 0}\right)$} \\
\hline CCI_G & 44 &, $20^{* * *}$ & ,37 & 4,98 & 000 \\
\hline CCI_O & 47 &, $03^{* *}$ & ,23 & 2,65 & 009 \\
\hline (Constant) & & & 6,515 & & \\
\hline \multicolumn{6}{|c|}{ SKÚ - Vnímaná zamestnatel'nost' $\left(\mathbf{F}_{\text {total }}(4,201)=11,616 ; \mathbf{p} \leq, \mathbf{0 0 0}\right)$} \\
\hline CCI_O & ,33 &, $11^{* * *}$ & ,58 & 4,11 & 000 \\
\hline CCI_G & ,37 &, $03^{* *}$ & ,35 & 3,02 & 004 \\
\hline CCI_E & 42 &, $03^{* *}$ & 2,96 & 2,57 & ,004 \\
\hline Vzdelanie & 43 &, $02^{*}$ & $-1,76$ & $-1,96$ & 05 \\
\hline (Constant) & & & 16,742 & & \\
\hline \multicolumn{6}{|c|}{ OKÚ - Plat $\left(\mathbf{F}_{\text {total }}(3,178)=10,897 ; \mathbf{p} \leq, \mathbf{0 0 0}\right)$} \\
\hline Vek & ,31 &, $07^{* * *}$ & 16,12 & 3,80 &, 000 \\
\hline Pohlavie & ,39 &, $06^{* * *}$ & $-3,19$ & $-3,46$ &, 001 \\
\hline CCI_C & ,17 &, $03^{*}$ &, 21 & 2,54 & 012 \\
\hline (Constant) & & & ,666 & & \\
\hline \multicolumn{6}{|c|}{ OKÚ - Počet povýšení $\left(\mathbf{F}_{\text {total }}(2,203)=14.110 ; \mathbf{p} \leq \mathbf{. 0 0 0}\right)$} \\
\hline CCI_O & 31 &, $10^{* * *}$ &, 06 & 3,02 & ,003 \\
\hline CCI_G & ,35 &, $02^{*}$ & ,04 & 2,36 & ,019 \\
\hline (Constant) & & &,- 803 & & \\
\hline
\end{tabular}

Poznámka: *** $\mathrm{p}<, 001, * * \mathrm{p}<, 01, * \mathrm{p} \leq, 05$; CCI_E - Efektivita súvisiaca s výkonom práce; CCI_G - Stanovenie ciel'ov a plánovanie kariéry; CCI_O-Znalost' firemnej politiky a štruktúr príležitostí; CCI_C - Zručnosti súvisiace s kariérou

Z výsledkov výpočtu viacnásobnej hierarchickej lineárnej regresie vyplýva, že kariérna spokojnost' (ako ukazovatel' SKÚ) má dva signifikantné prediktory, a to stanovenie ciel'ov a plánovanie kariéry (20\% variancie) a znalost' firemnej politiky a štruktúr príležitostí (3\% variancie). Dohromady tieto prediktory vysvetlili $23 \%$ variancie kariérnej spokojnosti. Kariérna spokojnost' jedinca je teda tým vyššia, čím vyššia je miera kariérnych kompetencií stanovenie ciel'ov a plánovanie kariéry a znalost' firemnej politiky a štruktúr príležitostí. V prípade vnímanej zamestnatel'nosti boli zistené štyri signifikantné prediktory, 
a to znalost' firemnej politiky a štruktúr príležitostí (11\% variancie), stanovenie ciel'ov a plánovanie kariéry (3\% variancie), efektivita súvisiaca s výkonom práce (3\% variancie) a vzdelanie (2\% variancie). Tieto prediktory dohromady vysvetlili $18 \%$ variancie vnímanej zamestnatel'nosti. Jedincom vnímaná zamestnatel'nost' je tým vyššia, čím vyššia je miera kariérnych kompetencií znalost' firemnej politiky a štruktúr príležitostí, stanovenie ciel'ov a plánovanie kariéry, efektivita súvisiaca s výkonom práce. Čo sa týka vzdelania, pomocou t-testu boli identifikované rozdiely v miere vnímanej zamestnatel'nosti, pričom vyššie skóre dosiahli stredoškolsky vzdelané osoby $(\mathrm{M}=32,60, \mathrm{SD}=5,80)$ oproti vysokoškolsky vzdelaným osobám $(\mathrm{M}=31,52, \mathrm{SD}=6,50)$. V prípade platu boli zistené 3 signifikantné prediktory, sociodemografické faktory vek (7\% variancie) a pohlavie (6\% variancie), a kompetencia zručnosti súvisiace s kariérou (3\% variancie). Dohromady tieto prediktory vysvetlili 16 \% variancie platu, pričom platí, že plat jedinca sa zvyšuje s narastajúcim vekom a mierou kariérnych zručností, a plat u mužov je vyšší než u žien. V prípade počtu povýšení boli zistené dva signifikantné prediktory, a to znalost' firemnej politiky a štruktúr príležitostí (10 \% variancie) a stanovenie ciel'ov a plánovanie kariéry (2 \% variancie), ktoré spolu vysvetlili $12 \%$ variancie počtu povýšení. Počet povýšení je u jedinca tým častejší, čím vyššia je miera kariérnych kompetencií znalost' firemnej politiky a štruktúr príležitostí a stanovenie ciel'ov a plánovanie kariéry.

\section{Diskusia}

V našom výskume sme predpokladali, že kariérne kompetencie budú pozitívne korelovat's kariérnym úspechom. Kariérny úspech sme v našom výskume sledovali pomocou štyroch ukazovatel'ov, a to kariérna spokojnost' a vnímaná zamestnatel'nost' ako ukazovatele subjektívneho kariérneho úspechu, a plat a počet povýšení ako ukazovatele objektívneho kariérneho úspechu. Zároveň sme sledovali, či dosahovanie kariérneho úspechu determinujú aj sociodemografické faktory vek, pohlavie a vzdelanie respondentov.

Korelácie medzi kariérnou spokojnost'ou a jednotlivými kariérnymi kompetenciami boli štatisticky významné a dosahovali hodnoty v rozmedzí od ,32 do ,44. Potvrdil sa náš predpoklad o pozitívnom vzt’ahu medzi kariérnymi kompetenciami a kariérnou spokojnost’ou, ako to bolo aj v prípade zahraničných štúdií (napr. Eby et al., 2003; Day \& Allen, 2004, Kuijpers \& Scheerens, 2006). Naše zistenia sú zároveň v zhode s výskumom Francis-Smythe et al. (2013), ktorí zistili, že k predikcii kariérnej spokojnosti významne prispievajú kariérne kompetencie stanovenie ciel’ov a plánovanie kariéry, znalost' firemnej politiky a štruktúr príležitostí, zručnosti súvisiace s kariérou, vytváranie siete kontaktov a vzt'ahov s mentormi, sebaprezentácia a hl'adanie spätnej väzby, ktoré dohromady vysvetlili $15 \%$ variancie kariérnej spokojnosti. V našom výskume kariérne kompetencie dohromady vysvetlili 23 \% variancie kariérnej spokojnosti, hoci len dve kariérne kompetencie sa ukázali ako signfikantné prediktory. Na základe výsledkov možno teda konštatovat', že jedinec, ktorý disponuje kariérnymi kompetenciami a v čím vyššej miere, je viac disponovaný efektívne riadit' svoju individuálnu kariéru a tým viac je s ňou spokojný. Čo sa týka sociodemografických faktorov, nepreukázali sa ako signifikantné prediktory kariérnej spokojnosti.

Ďalej nás zaujímalo, či kariérne kompetencie súvisia s konceptom vnímanej zamestnatel'nosti, ako to bolo potvrdené v niekol'kých štúdiách (napr. Akkermans, Brenninkmeijer, 
Huibers, \& Blonk, 2012). Vo výskume Ebyho et al. (2013) bol potvrdený pozitívny vzt’ah medzi vnímanou zamestnatel'nost'ou a kompetenciami sebapoznanie, kariérny vhl'ad, siete kontaktov a vzt'ahy s mentormi a kariérne zručnosti. Tieto kompetencie sú obsahovo totožné s kompetenciami $\mathrm{v}$ našom výskume, kde sme zistili signifikantné vzt’ahy medzi vnímanou zamestnatel'nost'ou a všetkými kariérnymi kompetenciami o sile ,20 až ,33. Eby et al. zároveň zistili, že k predikcii vnímanej internej zamestnatel'nosti najviac prispievajú kompetencie knowing-why (41,7 \%). Vnímanú externú zamestnatel'nost' vysvetlili v najväčšej miere kompetencie knowing-how (46,1 \%) (Eby et al., 2003). V našom výskume sa kariérne kompetencie tiež ukázali ako významné prediktory vnímanej zamestnatel’osti (16 \%). Podarilo sa nám teda podporit' predpoklad, že vnímaná zamestnatel'nost' (ako ukazovatel' SKÚ) je výsledkom kariérnych kompetencií, nakol'ko osvojenie kariérnych kompetencií by malo viest' jednotlivcov k pozitívnejšiemu vnímaniu ich schopnosti nájst' a udržat' si zamestnanie. Ako signifikantný prediktor zamestnatel'nosti sa zároveň preukázalo aj vzdelanie, avšak osoby so stredoškolským vzdelaním pocit’ujú vyššiu mieru zamestnatel'nosti ako vysokoškolsky vzdelané osoby, čo je $\mathrm{v}$ rozpore s našimi očakávaniami plynúcimi zo sociologickej teórie. Vysvetlenie týchto zistení možno spočíva v tom, že s narastajúcim počtom osôb s vysokoškolským vzdelaním klesá počet pracovných príležitosti pre ich uplatnenie na trhu práce vo svojom odbore a znižujúci sa záujem o vyučenie sa remesiel naopak utvrdzuje osoby s nižším vzdelaním o ich väčšej potrebe na pracovnom trhu.

V prípade objektívneho kariérneho úspechu, konkrétne platu, neboli preukázané štatisticky významné vzt’ahy s kariérnymi kompetenciami. Výnimkou bola len kompetencia zručnosti súvisiace s kariérou, ktorá vysvetlila $3 \%$ variancie priemerného mesačného platu. Rovnako aj vo výskume Francis-Smythe et al. (2013) k predikcii platu prispela len jedna kariérna kompetencia, a to stanovenie ciel’ov a plánovanie kariéry (11 \% variancie priemerného mesačného príjmu). Tieto rozdiely v zisteniach pramenia predovšetkým z kultúrnych odlišností skúmaných súborov. Spoločným zistením je však skutočnost', že plat je len vo vel'mi malej miere determinovaný kariérnymi kompetenciami. Naopak vo väčšej miere plat predikujú sociodemografické faktory, konkrétne vek a pohlavie (dohromady vysvetlili $13 \%$ variancie), čo sa zhoduje so sociologickými analýzami a zisteniami (napr. Horáková \& Horák, 2013, 2015; Matějů \& Anýžová, 2015).

Počet povýšení ako d’alšie kritérium objektívneho kariérneho úspechu, bol v štatisticky významnom pozitívnom vzt’ahu s takmer všetkými kariérnymi kompetenciami $(\mathrm{r}=, 26$ až ,31), bez vplyvu sociodemografických faktorov. To znamená, že s narastajúcou mierou kariérnych kompetencií narastá aj počet povýšení v kariére jednotlivca. Kariérne kompetencie v našom výskume vysvetlili $12 \%$ variancie počtu povýšení a vo výskume Francis-Smythe et al. (2013) kompetencie vysvetlili 4 \% variancie počtu povýšení.

Výnimkou medzi kariérnymi kompetenciami bola efektivita súvisiaca s výkonom práce, ktorá nebola v štatisticky významnom vzt’ahu s vnímanou zamestnatel'nost’ou, platom a ani počtom povýšení $(r=, 02$ až, 05$)$. To znamená, že táto kompetencia nezohráva až takú dôležitú úlohu pri úspešnom riadení kariéry jedinca. 


\section{Záver}

Účelom predkladaného príspevku bolo prispiet' $\mathrm{k}$ problematike kariérnych kompetencií, ktorá je v našich podmienkach málo rozpracovaná. V nami realizovanej štúdii sa nám podarilo preukázat', že kariérne kompetencie významne prispievajú k predikcii subjektívneho a objektívneho kariérneho úspechu. Výsledky nášho výskumu teda podporujú relevantnost' kariérnych kompetencií pri riadení úspešného kariérneho vývinu. Preto je dôležité im venovat' pozornost' a to nielen vo výskume, ale predovšetkým v praxi kariérového poradcu, pracovného psychológa, v oblasti riadenia l'udských zdrojov a pod. Odporúčame, aby títo odborníci pracovali s kariérnymi kompetenciami jednotlivcov a prostredníctvom ich merania, zhodnotenia, analýzy a rozvoja viedli jedincov k adekvátnemu riadeniu svojho kariérového vývinu.

\section{LITERATÚRA}

Akkermans, J., Brenninkmeijer, V., Huibers, M., \& Blonk, R. W. B. (2012). Competencies for the Contemporary Career: Development and Preliminary Validation of the Career Competencies Questionnaire. Journal of Career Development, 40(3), 245-267.

Arthur, M. B., \& Rousseau, D. M. (1996). The boundaryless career: A new employment principle for a new organizational era. New York: Oxford University Press.

Beheshtifar, M., \& Zare, E. (2013). Relationship between competencies career and organizational success. Interdisciplinary Journal of Contemporary Research in Business, 5 (1), 834-842.

Chang, H., Feng, CH., \& Shyu, CH. (2014). Individual management and counseling as moderators in achieving career competencies and success. Social Behavior and Personality, 42(5), 869-880.

Day, R., \& Allen, T. (2004). The relationship between career motivation and self-efficacy with protégé career success. Journal of Vocational Behavior, (64), 72-91.

De Cuyper, N., Bernhard-Oettel, C., Berntson, E., De Witte, H., \& Alarco, B. (2008). Employ-ability and employees' well-being: Mediation by job insecurity. Applied Psychology: An International Review, (57), 488-509.

DeFillippi, R. J., \& Arthur, M. B. (1994). The boundaryless career: A competency-based perspective. Journal of Organizational Behavior, (15), 307-324.

Dreher, G., \& Bretz, R. (1991). Cognitive ability and career attainment: The moderating effects of early career success. Journal of Applied Psychology, (76), 392-397.

Eby, L. T., Butts, M., \& Lockwood, A. (2003). Predictors of success in the era of the boundaryless career. Journal of Organizational Behavior, (24), 689-708.

Fields, D. L. (2002). Taking the measure of work: a guide to validated scales for organizational research and diagnosis. Thousand Oaks CA: Sage Publications.

Forret, M. L., \& Dougherry, T. W. (2004). Networking behaviors and career outcomes: Differences for men and women? Journal of Organizational Behavior, (25), 419437.

Francis-Smythe, J., Haase, S., Thomas, E., \& Steele, C. (2013). Development and Validation of the Career Competencies Indicator (CCI). Journal of Career Assessment, 21(2), 42-57.

Greenhause, J. H., Parasuraman, S. \& Wormley, W. M. (1990). Effects of Race on Organisational Experience, Job performance Evaluations, and Career Outcomes. Academy of Management Journal, 33(1), 64-86.

Higgins, M. C., \& Kram, K. E. (2001). Reconceptualizing mentoring at work: a developmental network perspective. Academy of Management Review, (26), 264-288.

Horáková, M., \& Horák, P. (2013). Zaměstnatelnost skupin ohrožených nezaměstnanosti na současných trzích práce. Sociológia, 45(2), 128-149.

Horák, P., \& Horáková, M. (2015). Zjišt'ování situace osob znevýhodněných na trhu práce prostřednictvím konceptu zaměstnatelnosti. Sociológia, 47(5), 451-473. 
Kubeš, M., Spillerová, D. \& Kurnický, R. (2004). Manažerské kompetence. Způsobilosti výjimečných manažerů. Praha: Grada Publishing.

Kuijpers, M., \& Scheerens, J. (2006). Career Competencies for the Modern Career. Journal of Career Development, 32(4), 303-319.

Kuijpers, M., Schyns, B., \& Scheerens, J. (2006). Career Competencies for Career Success. The Career Development Quarterly, 55(2), 168-178.

Lichtenstein, B. \& Mendenhall, M. (2002). Non-linearity and response-ability: Emergent order in 21st-century careers. Human Relations, (55), 5-32.

Lo Presti, A. (2009). Snakes and ladders: stressing the role of meta-competencies for post-modern careers. Journal of Educational and Vocational Guidance, (9), 125-134.

Matějů, P., Anýžová, P. (2015). Role lidského kapitálu v úspěchu na trhu práce: srovnání šesti evropských zemí participujících na prijektu PIAAC. Sociológia, 47(1), 31-65.

Ng, T. W. H., Eby, L. T., Sorensen, K. L., \& Feldman, D. C. (2005). Predictors of objective and subjective career success: A meta-analysis. Personnel Psychology, (58), 367-408.

Singh, R., Ragins, B., \& Tharenou, P. (2009). What matters most? The relative role of mentoring and career capital in career success. Journal of Vocational Behavior, (75), 56-67.

\title{
CAREER COMPETENCIES AS PREDICTORS OF CAREER SUCCESS
}

\author{
I. MAGÁČOVÁ ŽILKOVÁ
}

\section{ABSTRACT}

The presented article is focused on concept of career competencies. The aim of the research was to find a relationships between career competencies and career success. Career competencies was meaasured by the Career Competencies Indicator (CCI). Four indicators of subjective and objective career success were examined, namely, career satisfaction, perceived employability, salary and number of promotions. The sample consisted of 206 employed people with an average age of 29.45. Correlation Coefficients and Multiple Hierarchical Linear Regression was used to statistical data analysis. The results showed a significant positive relationship between career competencies and career satisfaction, perceived employability, and the number of promotions. The results of research support the importance of career competencies for successful career development.

Keywords: career competencies, career success, career counseling, Slovak republic

O autorce: PhDr. Ivana Magáčová Žilková, PhD. - pôsobi na Katedre pedagogiky Fakulty humanitných a prírodných vied Prešovskej univerzity v Prešove, kde vyučuje psychologické discipliny so zameraním na oblast’ všeobecnej, pedagogickej a sociálnej psychológie. Zaoberá sa problematikou kariérového poradenstva a metodologickým otázkam validácie výskumných a diagnostických nástrojov. Je spoluriešitel'kou na výskumných projektoch VEGA ,Kariérové rozhodovania adolescentov “ a „Overenie možnosti zmeny profesijných záujmov pomocou simulácie profesijnej explorácie“. E-mail: ivana.magacova.zilkova @unipo.sk 